\title{
Antimicrobial resistance in bacteria isolated from pigs with respiratory clinical signs in Brazil
}

\section{Resistência a antimicrobianos em bactérias isoladas de suínos com sinais clínicos respiratórios no Brasil}

\author{
Maysa Serpa $^{1}$ (D); Juliana Amália Fonte Bôa do Nascimento²; Mirian Fátima Alves'; \\ Maria Isabel Maldonado Coelho Guedes ${ }^{2}$ (D); Adrienny Trindade Reis ${ }^{3}$; Marcos Bryan Heinemann ${ }^{4}$ (D); \\ Andrey Pereira Lage ${ }^{2}$ (D); Zélia Inês Portela Lobato² (iD; Elaine Maria Seles Dorneles ${ }^{1}$ \\ ${ }^{1}$ Universidade Federal de Lavras, Departamento de Medicina Veterinária, Lavras - MG, Brasil \\ ${ }^{2}$ Universidade Federal de Minas Gerais, Escola de Veterinária, Departamento de Medicina Veterinária Preventiva, Belo Horizonte - MG, Brasil \\ ${ }^{3}$ Instituto de Pesquisas Veterinárias Especializadas, Belo Horizonte - MG, Brasil \\ ${ }^{4}$ Universidade de São Paulo, Faculdade de Medicina Veterinária e Zootecnia, Departamento de Medicina Veterinária Preventiva e Saúde \\ Animal, São Paulo - SP, Brasil
}

\begin{abstract}
Antimicrobial resistance is a current and important issue to public health, and it is usually associated with the indiscriminate use of antimicrobials in animal production. This study aimed to evaluate the antimicrobial susceptibility profile in bacterial isolates from pigs with clinical respiratory signs in Brazil. One hundred sixty bacterial strains isolated from pigs from 51 pig farms in Brazil were studied. In vitro disk-diffusion method was employed using 14 antimicrobial agents: amoxicillin, penicillin, ceftiofur, ciprofloxacin, enrofloxacin, chlortetracycline, doxycycline, oxytetracycline, tetracycline, erythromycin, tilmicosin, florfenicol, lincomycin, and sulfadiazine/trimethoprim. The majority of isolates were resistant to at least one antimicrobial agent $(98.75 \% ; 158 / 160)$, while $31.25 \%$ (50/160) of the strains were multidrug resistant. Streptococcus suis and Bordetella bronchiseptica were the pathogens that showed higher resistance levels. Haemophilus parasuis showed high resistance levels to sulfadiazine/trimethoprim $(9 / 18=50 \%)$. We observed that isolates from the midwestern and southern regions exhibited four times greater chance of being multidrug resistant than the isolates from the southeastern region studied. Overall, the results of the present study showed a great level of resistance to lincomycin, erythromycin, sulfadiazine/trimethoprim, and tetracycline among bacterial respiratory pathogens isolated from pigs in Brazil. The high levels of antimicrobial resistance in swine respiratory bacterial pathogens highlight the need for the proper use of antimicrobials in Brazilian pig farms.
\end{abstract}

Keywords: Multidrug resistance. Streptococcus suis. Pasteurella multocida. Haemophilus parasuis. Actinobacillus pleuropneumoniae. Bordetella bronchiseptica.

\section{RESUMO}

A resistência antimicrobiana é uma questão atual e muito importante para a saúde pública, geralmente associada ao uso indiscriminado de antimicrobianos na produção animal. Diante disso, foi investigado o perfil de sensibilidade-antimicrobiana em isolados bacterianos de suínos com sinais clínicos respiratórios no Brasil. Foram estudadas 96 isolados provenientes de 51 granjas de suínos do Brasil. O método de disco-difusão foi empregado usando 14 antimicrobianos: amoxicilina, penicilina, ceftiofur, ciprofloxacina, enrofloxacina, clortetraciclina, doxiciclina, oxitetraciclina, tetraciclina, eritromicina, tilmicosina, florfenicol, lincomicina e sulfadiazina/trimetoprim. Streptococcus suis e Bordetella bronchiseptica foram os patógenos que apresentaram maiores níveis de resistência. Haemophilus parasuis apresentou altos níveis de resistência à sulfadiazina/trimetoprim (9/18=50\%). Observou-se que isolados das regiões Centro-Oeste e Sul apresentaram quatro vezes mais chance de serem multirresistentes do que os isolados da região Sudeste. A maioria foi resistente a pelo menos um agente antimicrobiano (98,75\%; 158/160) e $31,25 \%$ (50/160) das estirpes isoladas eram multirresistentes. No geral, os resultados do presente estudo mostraram grande nível de resistência à lincomicina, eritromicina, sulfadiazina/trimetoprim e tetraciclina entre patógenos respiratórios bacterianos isolados de suínos no Brasil. Os altos níveis de resistência antimicrobiana em patógenos bacterianos respiratórios em suínos reforçam a necessidade do uso criterioso de antimicrobianos na suinocultura brasileira.

Palavras-chave: Resistência múltipla aos antimicrobianos. Streptococcus suis. Pasteurella multocida. Haemophilus parasuis. Actinobacillus pleuropneumoniae. Bordetella bronchiseptica. 
Correspondence to:

Elaine Maria Seles Dorneles

Universidade Federal de Lavras, Departamento de Medicina

Veterinária

Av. Doutor Sylvio Menicucci, 1001

CEP: 37200-000, Lavras - MG, Brasil

e-mail: elaine.dorneles@ufla.br

Received: August 12, 2019

Approved: October 16, 2019

How to cite: Serpa M, Nascimento JAFB, Alves MF, Guedes MIMC, Reis AT, Heinemann MB, Lage AP, Lobato ZIP, Dorneles EMS. Antimicrobial resistance in bacteria isolated from pigs with respiratory clinical signs in Brazil. Braz J Vet Res Anim Sci. 2020;57(1):e160956. https://doi. org/10.11606/issn.1678-4456.bjvras.2020.160956

\section{Introduction}

Currently, swine is the main source of protein consumed worldwide and Brazil is the fourth largest producer and exporter of these animals (Associação Brasileira de Proteína Animal, 2018). To meet the growing demand for swine, intensive systems have been increasingly used and, consequently, the risk of infectious diseases becomes greater (Heres et al., 2013). Animal density and other adverse conditions favor the introduction and dissemination of respiratory disease agents (Dayao et al., 2014).

Respiratory diseases in pigs are multifactorial pathologies influenced by the interaction of several microorganisms, in addition to genetic and environmental factors, which cause significant decreases in production and productivity, resulting in high economic losses for pig farms (Jong et al., 2014; El Garch et al., 2016). The bacterial agents associated with respiratory clinical signs are often commensal and opportunistic bacteria of the respiratory tract that play an important role in the infection, exacerbating the clinical signs and causing more severe lesions (Opriessnig et al., 2011). Among the most important bacterial pathogens involved in swine respiratory diseases are Pasteurella multocida, Streptococcus suis, Haemophilus parasuis, Actinobacillus pleuropneumoniae, Mycoplasma hyopneumoniae, and Bordetella bronchiseptica (Opriessnig et al., 2011; Jong et al., 2014; Dayao et al., 2016).

Control of these respiratory infections in pigs is usually performed by administering antimicrobials. However, the indiscriminate use of these drugs can lead to a rapid selection and dissemination of resistance among bacterial pathogens. The increasing level of multidrug resistant (MDR) bacteria is a potential risk to public health and may hinder the treatment of animal and human infections (Jong et al., 2014). Thus, this study aimed to evaluate the antimicrobial susceptibility profile of bacterial pathogens isolated from pigs with respiratory clinical signs in Brazil.

\section{Materials and Methods}

This study used non-probabilistic sampling obtained from data of a private laboratory. One hundred sixty bacterial strains isolated from pigs with clinical respiratory signs from 51 pig farms in Brazil were studied, as follows: P. multocida [78/160 (48.75\%)] S. suis [42/160 (26.25\%)], H. parasuis [18/160 (11.25\%)], A. pleuropneumoniae [17/160 (10.62\%)], and B. bronchiseptica [5/160 (3.12\%)]. Clinical samples were collected by veterinary practitioners between May 2006 and November 2007 and processed by a private veterinary diagnostic laboratory (Institute of Specialized Veterinary Research (IPEVE), Belo Horizonte, Brazil). The pig farms were from nine Brazilian states in the midwestern, southeastern and southern regions, comprising the major swine production areas in the country. The distribution of isolates by Brazilian state and region is shown in Table 1 .

In vitro antimicrobial susceptibility tests were performed by the disk-diffusion method in accordance with the recommendations of the Clinical and Laboratory Standards Institute (CLSI) M132-A2 manual (National Committee for Clinical Laboratory Standards, 2002), and the isolates were classified as resistant, intermediate, or susceptible according to the following references: CLSI manuals supplement VET08 and M100 (Clinical Laboratory Standards Institute, 2018a, b), EUCAST, CLSI-potency Neo-Sensitabs ${ }^{\text {Tw }}$ User's Guide (Rosco Diagnostica, 2013), Lönnqvist et al. (2018), and Kim et al. (2016). The breakpoints used are detailed in the supplementary material. Multidrug resistance (MDR) was defined as resistance to three or more antimicrobial groups (Magiorakos et al., 2011). The following antimicrobial groups were tested: 1) penicillins (amoxicillin $10 \mu \mathrm{g}$ and penicillin $\mathrm{G} 10 \mu \mathrm{g}$ ); 2) cephalosporins (ceftiofur $30 \mu \mathrm{g}$ ); 3) fluoroquinolones (enrofloxacin $5 \mu \mathrm{g}$ and ciprofloxacin $5 \mu \mathrm{g}$ ); 4) tetracyclines (tetracycline $30 \mu \mathrm{g}$, chlortetracycline $10 \mu \mathrm{g}$, doxycycline $30 \mu \mathrm{g}$ and oxytetracycline $30 \mu \mathrm{g}$ ); 5) macrolides (erythromycin $30 \mu \mathrm{g}$, and tilmicosin $15 \mu \mathrm{g}$ ); 6) amphenicols (florfenicol $30 \mu \mathrm{g}$ ); 7) lincosamides (lincomycin $2 \mu \mathrm{g}$ ), and 8) folate pathway inhibitors (sulfadiazine + trimethoprim $25 \mu \mathrm{g}$ ). Isolates were tested for different antimicrobial agents according to the bacterial species and the request of the pig farm veterinarian. The antimicrobial agents tested in $90 \%$ or more bacterial isolates were amoxicillin, ceftiofur, 
Table 1. Bacterial species isolated from tissue samples of pigs with respiratory clinical signs from nine Brazilian states, between May 2006 and November 2007

\begin{tabular}{|c|c|c|c|c|c|c|}
\hline State $^{a}$ & $\begin{array}{c}\text { Pasteurella } \\
\text { multocida }\end{array}$ & Streptococcus suis & $\begin{array}{c}\text { Haemophilus } \\
\text { parasuis }\end{array}$ & $\begin{array}{c}\text { Actinobacillus } \\
\text { pleuropneumoniae }\end{array}$ & $\begin{array}{c}\text { Bordetella } \\
\text { bronchiseptica }\end{array}$ & Total \\
\hline MG & 35 & 14 & 11 & 9 & 1 & 71 \\
\hline MT & 15 & 6 & 2 & 2 & 0 & 25 \\
\hline MS & 5 & 3 & 1 & 6 & 1 & 16 \\
\hline GO & 2 & 7 & 1 & 0 & 3 & 13 \\
\hline SC & 6 & 2 & 3 & 0 & 0 & 11 \\
\hline RS & 2 & 8 & 0 & 0 & 0 & 10 \\
\hline SP & 5 & 2 & 0 & 0 & 0 & 7 \\
\hline PR & 4 & 0 & 0 & 0 & 0 & 4 \\
\hline ES & 4 & 0 & 0 & 0 & 0 & 4 \\
\hline Total & 78 & 42 & 18 & 17 & 5 & 160 \\
\hline
\end{tabular}

${ }^{a}$ Minas Gerais (MG); Mato Grosso (MT); Mato Grosso do Sul (MS); Goiás (GO); Santa Catarina (SC); Rio Grande do Sul (RS); São Paulo (SP); Paraná (PR); Espírito Santo (ES). Midwest region states (MT, MS, GO); Southeast region states (MG, SP, ES); South region states (SC, PR, RS).

Table 2. Antimicrobial susceptibility of bacterial pathogens isolated from pigs with respiratory clinical signs, between May 2006 and November 2007, Samples collected from nine different states from Midweast, Southeast and South of Brazil

\begin{tabular}{|c|c|c|c|c|c|c|c|c|c|c|c|c|c|c|c|}
\hline \multirow[t]{2}{*}{ Antimicrobials } & \multicolumn{3}{|c|}{$\begin{array}{c}\text { Actinobacillus } \\
\text { pleuropneumoniae }\end{array}$} & \multicolumn{3}{|c|}{ Streptococcus suis } & \multicolumn{3}{|c|}{$\begin{array}{c}\text { Bordetella } \\
\text { bronchiseptica }\end{array}$} & \multicolumn{3}{|c|}{$\begin{array}{c}\text { Pasteurella } \\
\text { multocida }\end{array}$} & \multicolumn{3}{|c|}{$\begin{array}{c}\text { Haemophilus } \\
\text { parasuis }\end{array}$} \\
\hline & ${ }^{\mathrm{a}} \mathbf{R} \%$ & ${ }^{\mathrm{b}} \mathrm{S} \%$ & $\mathbf{~} \mathbf{0}$ & $\mathbf{R} \%$ & S\% & $1 \%$ & $\mathbf{R} \%$ & $\mathbf{S} \%$ & $1 \%$ & $\mathbf{R} \%$ & $\mathbf{S} \%$ & $1 \%$ & $\mathbf{R} \%$ & $\mathbf{S} \%$ & $1 \%$ \\
\hline Amoxicillin & 0.00 & 88.24 & 11.76 & 0.00 & 100.00 & 0.00 & 100.00 & 0.00 & 0.00 & 3.84 & 94.88 & 1.28 & 0.00 & 100.00 & 0.00 \\
\hline Penicillin & 11.76 & 76.47 & 11.76 & 2.38 & 95.24 & 2.38 & 100.00 & 0.00 & 0.00 & 0.00 & 92.31 & 7.69 & 5.56 & 94.44 & 0.00 \\
\hline Ceftiofur & 0.00 & 100.00 & 0.00 & 0.00 & 100.00 & 0.00 & & ${ }^{d} N T$ & & 1.28 & 97.44 & 1.28 & 0.00 & 100.00 & 0.00 \\
\hline Ciprofloxacin & 11.76 & 88.24 & 0.00 & 30.95 & 50.00 & 19.05 & 0.00 & 80.00 & 20.00 & 2.56 & 96.16 & 1.28 & 0.00 & 100.00 & 0.00 \\
\hline Enrofloxacin & 11.76 & 82.35 & 5.88 & 7.14 & 59.52 & 33.33 & 0.00 & 60.00 & 40.00 & 1.28 & 85.90 & 12.82 & 11.11 & 88.89 & 0.00 \\
\hline Chlortetracycline & 0.00 & 81.82 & 18.18 & 73.08 & 7.69 & 19.23 & & NT & & 16.07 & 78.57 & 5.36 & 0.00 & 90.91 & 9.09 \\
\hline Doxycycline & 0.00 & 94.12 & 5.88 & 28.57 & 38.10 & 33.33 & & NT & & 3.84 & 96.16 & 0.00 & 0.00 & 100.00 & 0.00 \\
\hline Oxytetracycline & 36.36 & 18.18 & 45.45 & 57.69 & 30.77 & 11.54 & & NT & & 25.00 & 75.00 & 0.00 & 9.09 & 90.91 & 0.00 \\
\hline Tetracycline & 100.00 & 0.00 & 0.00 & 100.00 & 0.00 & 0.00 & & NT & & 18.18 & 54.55 & 27.27 & 0.00 & 42.86 & 57.14 \\
\hline Erythromycin & 42.86 & 21.43 & 35.71 & 94.59 & 0.00 & 5.41 & 100.00 & 0.00 & 0.00 & 14.52 & 50.00 & 35.48 & 5.88 & 82.35 & 11.76 \\
\hline Tilmicosin & 0.00 & 82.35 & 17.65 & 90.48 & 7.14 & 2.38 & 100.00 & 0.00 & 0.00 & 12.82 & 85.90 & 1.28 & 0.00 & 77.78 & 22.22 \\
\hline Florfenicol & 0.00 & 100.00 & 0.00 & 11.90 & 88.10 & 0.00 & 0.00 & 100.00 & 0.00 & 2.56 & 97.44 & 0.00 & 0.00 & 100.00 & 0.00 \\
\hline Lincomycin & 64.71 & 17.65 & 17.65 & 95.24 & 4.76 & 0.00 & & NT & & 61.54 & 15.38 & 23.07 & 0.00 & 61.11 & 38.89 \\
\hline $\begin{array}{l}\text { Sulfadiazine }+ \\
\text { trimethoprim }\end{array}$ & 11.76 & 88.24 & 0.00 & 40.48 & 57.14 & 2.38 & 100.00 & 0.00 & 0.00 & 20.51 & 69.23 & 23.07 & 0.00 & 61.11 & 38.89 \\
\hline
\end{tabular}

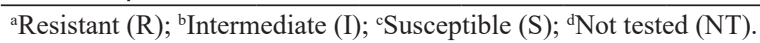

ciprofloxacin, doxycycline, enrofloxacin, florfenicol, lincomycin, sulfadiazine/trimethoprim, and penicillin.

Data from all 160 consecutive samples of pigs with respiratory disorders were collected from the laboratory recording files and organized in a database using Microsoft ${ }^{\circledR}$ Office Excel ${ }^{\circledR} 2007$ (Redmond, WA, USA). Descriptive analyses of the antimicrobial susceptibility profile of the strain and location of pig farm, season, and bacterial species isolated were performed. The Chi-square test and the odds ratio were calculated using the EpiInfo ${ }^{\text {tw }}$ software version 7.2.2.6 (Centers for Disease Control and Prevention [CDC], USA).

\section{Results}

The percentages of isolates classified as resistant, intermediate or susceptible for each antimicrobial are shown in Table 2. Resistance of the isolates was observed mainly to lincomycin, erythromycin, sulfadiazine/trimethoprim, and tetracyclines.

Susceptibility profiles were constructed for each bacterial species based on the antimicrobial groups. Only the antimicrobial groups that were tested for all strains of the species were used for the construction of those profiles (Table 3). Twenty-eight profiles were observed for P. multocida, 17 for S. suis, 10 for $H$. parasuis, 9 for A. pleuropneumoniae, and 1 for B. bronchiseptica. (Figure 1).

A comparison of the resistance levels of bacterial species isolated from pig respiratory disorders by antimicrobial groups among the Brazilian regions is shown in Figure 2. S. suis showed higher levels of resistance compared to $P$. multocida, A. pleuropneumoniae and $H$. parasuis. For $H$. parasuis, resistance was observed mostly to sulfadiazine/trimethoprim. All B. bronchiseptica strains exhibited resistance to five 
Table 3. Percentage of bacterial isolates isolated from pigs with respiratory clinical signs tested for each antimicrobial, 2006-2007, Brazil

\begin{tabular}{|c|c|c|c|c|c|}
\hline \multirow{2}{*}{ Antimicrobial } & \multicolumn{5}{|c|}{ Isolates tested (\%)* } \\
\hline & Ap $(n=17)$ & Ss $(n=42)$ & $\mathrm{Bb}(\mathrm{n}=5)$ & $\operatorname{Pm}(n=78)$ & $\mathrm{Hp}(\mathrm{n}=18)$ \\
\hline Amoxicillin & 88.24 & 100.00 & 100.00 & 100.00 & 100.00 \\
\hline Ceftiofur & 100.00 & 100.00 & NT & 100.00 & 100.00 \\
\hline Ciprofloxacin & 88.24 & 100.00 & 100.00 & 100.00 & 100.00 \\
\hline Chlortetracycline & 64.71 & 61.90 & NT & 71.79 & 61.11 \\
\hline Doxycycline & 100.00 & 100.00 & NT & 100.00 & 100.00 \\
\hline Enrofloxacin & 100.00 & 100.00 & 100.00 & 100.00 & 100.00 \\
\hline Erythromycin & 82.35 & 88.10 & 100.00 & 80.77 & 94.44 \\
\hline Florfenicol & 100.00 & 100.00 & 100.00 & 100.00 & 100.00 \\
\hline Lincomycin & 100.00 & 100.00 & NT & 100.00 & 100.00 \\
\hline Oxytetracycline & 64.71 & 61.90 & NT & 71.79 & 61.11 \\
\hline Sulfadiazine + trimethoprim & 100.00 & 100.00 & 100.00 & 100.00 & 100.00 \\
\hline Penicillin & 100.00 & 100.00 & 100.00 & 100.00 & 100.00 \\
\hline Tetracycline & 41.18 & 38.10 & NT & 28.21 & 38.89 \\
\hline Tilmicosin & 100.00 & 100.00 & 100.00 & 100.00 & 100.00 \\
\hline
\end{tabular}

*Actinobacillus pleuropneumoniae (Ap); Streptococcus suis (Ss); Bordetella bronchiseptica (Bb); Pasteurella multocida (Pm); Haemophillus parasuis (Hp).
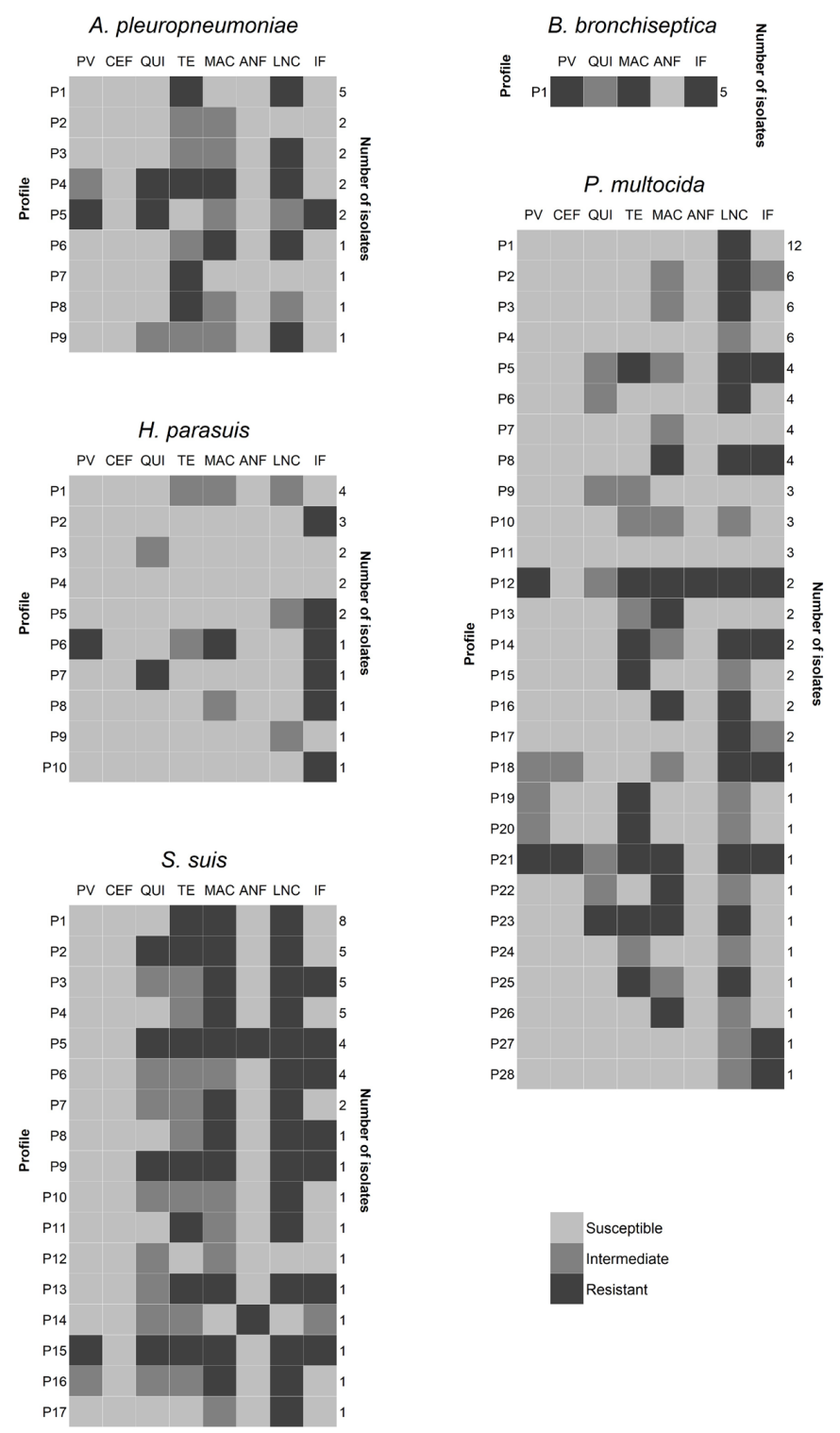

Figure 1. Antimicrobial susceptibility profiles of Actinobacillus pleuropneumoniae, Haemophilus parasuis, Streptococcus suis, Bordetella bronchiseptica, and Pasteurella multocida isolated from pigs with respiratory clinical signs in nine states of midweast, southeast and south of Brazil, from May 2006 to November 2007. Penicillins (PV), Cephalosporins (CEF), Quinolones (QUI), Tetracyclines (TE), Macrolides (MAC), Anfenicois (ANF), Lincosamides (LNC), Folate Pathway Inhibitors (IF), and Diterpenoids (DIF). 

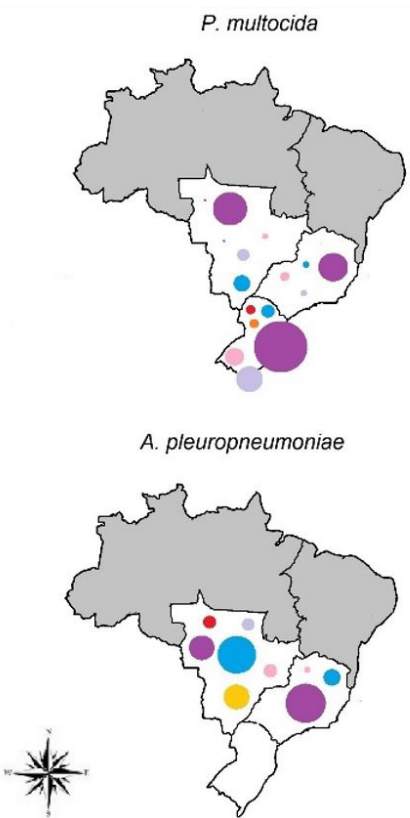
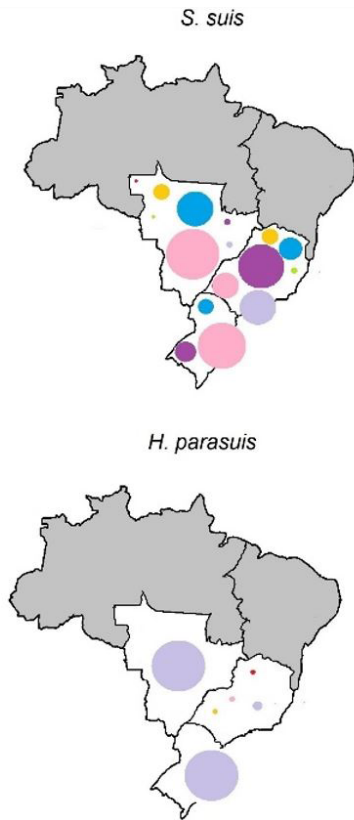
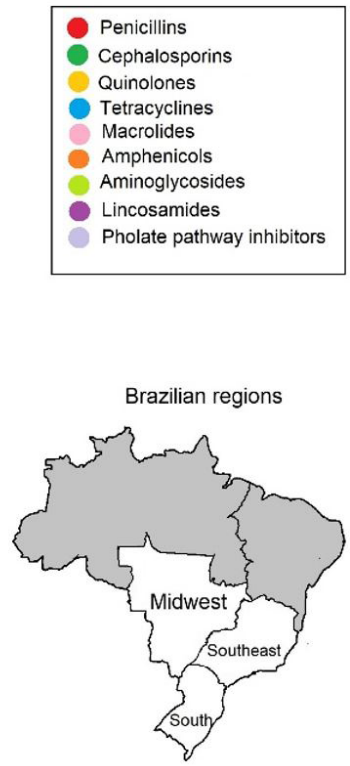

Figure 2. Resistance profiles of Pasteurella multocida, Streptococcus suis, Actinobacillus pleuropneumoniae and Haemophilus parasuis isolated from pigs with respiratory clinical signs to different antimicrobial groups in Midwest, Southeast, and South regions of Brazil, between May 2006 and November 2007. The diameter of the circles is proportional to the percentage of strains in the region classified as resistant.

Table 4. Frequency of multidrug resistance (MDR) among bacterial isolates from pigs with respiratory clinical signs in nine different states of midweast, southeast and south of Brazil; between May 2006 and November 2007

\begin{tabular}{lccc}
\hline \multicolumn{1}{c}{ Bacteria Species } & Total of Isolates & Number & Percentage \\
\cline { 3 - 4 } & & 14 & 17.95 \\
Pasteurella multocida & 78 & 26 & 61.90 \\
Streptococcus suis & 42 & 1 & 5.55 \\
Haemophilus parasuis & 18 & 4 & 23.52 \\
Actinobacillus pleuropneumoniae & 17 & 3 & 60.00 \\
Bordetella bronchiseptica & 5 & 50 & 30.00 \\
Total & 160 & & \\
\hline
\end{tabular}

antimicrobials (Table 2) tested and were classified as MDR. A total of $50[50 / 160(31.25 \%)]$ of all isolates were considered MDR. The frequency of MDR strains by bacterial species is shown in Table 4. Midwestern and southern regions exhibited significantly higher proportion of MDR isolates, $86.21 \%$ and $78.57 \%$, respectively, compared to southeastern region $(22.73 \%)$ (Chi-square $\chi^{2}=13.5189 ; \mathrm{P}=0.0011$ ). Isolates from the southeastern region exhibited about $70 \%$ less chance to be classified as MDR compared to isolates from the midwestern [Odds ratio $(\mathrm{OR})=0.2636$; $95 \%$ confidence interval (CI): 0.1215 to 0.5722 ] and southern $(\mathrm{OR}=0.2893 ; 95 \% \mathrm{CI}: 0.1092$ to 0.7858$)$ regions. In contrast, no association between resistance profile and the season sampling was observed.

\section{Discussion}

The establishment of the frequency of the bacterial pathogens associated with porcine respiratory disease in Brazil was not the aim of this study, but results obtained reflect the frequency of the most common bacterial pathogens associated with respiratory clinical disorders in swine raised worldwide. Therefore, it was possible to draw several conclusions about the antimicrobial susceptibility profile of the isolates and, especially, about the high frequency of MDR isolates observed in the sampling, mainly among S. suis and B. bronchiseptica. Moreover, the obtained results pointed to a significant level of resistance to lincomycin, erythromycin, sulfadiazine/trimethoprim, and tetracycline among bacterial respiratory pathogens isolated.

Compared with other species, $H$. parasuis showed a different resistance profile (Figure 2), being highly resistant to sulfadiazine/trimethoprim. Similar results were observed in China where a high level of resistance to sulfonamides (44.5\%) were also found among $H$. parasuis clinical isolates (Zhou et al., 2010). The high resistance to sulfadiazine/trimethoprim found by Zhao et al. (2018) could be related to the presence of sull and sul2 genes, which has been associated with sulfonamide resistance in this 
species. S. suis, in turn, showed high resistance to several drugs (mainly macrolides and tetracyclines) and half of the isolates were MDR (Table 2 and Figure 1), which were distributed among all studied regions (Figure 2). Similar studies also revealed high levels of resistance among S. suis, mainly to tetracycline (Portis \& Lindeman, 2013; Jong et al., 2014). The high levels of resistance for this pathogen have been associated with the massive use of antimicrobials in swine, which is especially important considering that this agent is an important zoonotic pathogen (Palmieri et al., 2011). At that, the high number of MDR strains and the wide distribution of S. suis in the regions from where the samples were collected are very alarming, since these strains can infect humans. Moreover, S. suis infections are difficult to track, representing an important link between human and animal health.

Likewise, although the distribution is not as wide as that of S. suis, the resistance levels found in B. bronchiseptica isolated in Brazil is also disturbing. Many resistant $B$. bronchiseptica strains isolated from pigs were also observed by Dayao et al. (2014) in Australia. Furthermore, it is important to take into account that the majority of the resistance genes found in this pathogen are localized in plasmids, and B. bronchiseptica-induced infections are frequently associated with coinfections (mainly with $P$. multocida) (Opriessnig et al., 2011; Kadlec \& Schwarz, 2018; Niemann et al., 2018). The polymicrobial environment of the coinfections can facilitate the gene transference between strains, even to other species, which may explain the results observed in the present study, as well as results obtained in Australia. Therefore, it is important to highlight that B. bronchiseptica is a relevant pathogen in respiratory diseases in swine, since, in addition to its ability to acquire resistance genes, it may still be the source of resistance gene to other species, such as P. multocida and A. pleuropneumoniae (Furian et al., 2016), which are commensal bacteria in swine respiratory tract. Indeed, we observed high levels of resistance in these species (P. multocida and A. pleuropneumoniae), mainly to lincomycin and tetracycline. Similar results were observed in other studies performed in China, Australia, and Europa (Tang et al., 2009; Dayao et al., 2014; Jong et al., 2014), suggesting that resistance to tetracycline and lincomycin is widespread among swine.

The use of antimicrobials as growth promoters is usually incriminated as one of the main causes for the emerging high number of resistant bacteria (S. suis, for instance), which has major public health consequences. However, as secondary data registered in the present study, it is not possible to determine whether bacterial isolates were from swine exposed to antimicrobial treatment, although this is highly likely since this practice was very common in Brazil at the sampling time. Moreover, it is tempting to speculate that the use of antimicrobials as growth promoters, despite being frequent throughout the country, was less frequent in pig farms from the southeastern region, since a significantly lower level of resistance among bacterial isolates from this region was observed in comparison with strains from the other regions. At present, this practice is still frequent in Brazil (Dutra, 2017), although some antimicrobials are now forbidden to be used as growth promoters, and some farms have completely abolished the use of antimicrobials in pig production.

In Brazil, records on the sale of antimicrobials for animal use are not available, mainly for animal production. Consequently, there are inconsistent data on the drugs most commonly used as growth promoters and those that are used to prevent diseases in pig farming. Furthermore, there are only a few studies on antimicrobial resistance in bacteria isolated from pigs with respiratory diseases in this country. The absence of these information precludes the direct causal association between the high levels of resistance observed and the major antimicrobials used in pig production, in addition to substantial comparisons between the results obtained in this study and in other countries. However, an investigation performed in 25 pig farms in Brazil showed that the lincosamide class was used in $52.0 \%$, macrolides in $48.0 \%$, and tetracyclines in $80.0 \%$ of the pig farms assessed (Dutra, 2017). Furian et al. (2016), also in Brazil, found high levels of resistance to tetracycline, folate inhibitors and erythromycin in P. multocida, suggesting that these resistance profiles may be frequent among pulmonary bacteria from Brazilian pig herds. In addition, even indirectly, the obtained results can also be compared with those found in countries with swine production systems similar to the one observed in Brazil, allowing the inference that the resistance to lincomycin, sulfadiazine/trimethoprim, and tetracycline classes observed in the present investigation are very likely due to the use of these drugs as growth promoters. In fact, in China, Tang et al. (2009) also found resistance to lincomycin, sulfadiazine/trimethoprim, and tetracyclines in P. multocida isolated from swine. Similarly, Dayao et al. $(2014,2016)$ in Australia and Portis \& Lindeman (2013), in Canada and the United States, also observed resistance to tetracycline among porcine respiratory pathogens. Moreover, Carlson \& Fangman (2000) mentioned that, in the United States, sulfadiazine/trimethoprim and tetracyclines are commonly used as growth promoters, as well as lincomycin, which is also used to prevent diseases. 
In contrast, in Europe, the use of antimicrobials as growth promoters has been prohibited since 2003. Even so, recent studies performed in European countries revealed strains resistant to tetracycline and higher values of minimal inhibitory concentration to lincomycin, suggesting that the consequences of using antimicrobials persist even after years of abstinence (Jong et al., 2014; El Garch et al., 2016). The most important cost of the reckless use of antimicrobials is the emergence of MDR bacteria, which are a potential risk to public health (Landers et al., 2012; Jong et al., 2014). Hence, there has been an important decrease in the number of countries worldwide that allow the use of antimicrobials as growth promoters (World Organisation for Animal Health, 2016). The high number of MDR and their widespread distribution in the three Brazilian regions, which concentrate the country pig production (Associação Brasileira de Proteína Animal, 2018) (Figure 2) observed in this study, highlights the importance of the careful use of antimicrobials in animal production. Brazil is a major producer and exporter of swine and, due to the demands of importing countries, the use of antimicrobials in animal production has been increasingly controlled and many antimicrobial groups (tylosin, lincomycin, virginiamycin, bacitracin and tiamulin) considered important in human medicine were recently abolished by law (Ministério da Agricultura, Agropecuária e Abastecimento, 2018). Although the present results reflected the reality of a decade ago, they are very alarming, since most of the strains were resistant to at least one antimicrobial agent $(98.75 \%, 158 / 160)$ and $31.25 \%$ (50/160) of the strains were MDR. Currently, bacterial resistance status is probably very similar or even worse, since the use of antimicrobials as growth promoters

\section{References}

Associação Brasileira de Proteína Animal. Relatório Anual 2018. São Paulo: ABPA; 2018 [cited 2019 Aug 28]. Available from: http://abpa-br.com.br/storage/files/ relatorio-anual-2018.pdf

Carlson MS, Fangman TJ. Swine antibitics and feed additives: food safety considerations. Columbia: University of Misouri; 2000.

Clinical Laboratory Standards Institute. Performance standards for antimicrobial disk and diluition susceptibility test of bacteria isolated from animals. 4 th ed. Wayne, PA: CLSI; 2018a [cited 2019 Aug 28]. Available from: https:// standards.globalspec.com/std/10393524/clsi-vet08 are still frequent and were intensively used through these years. Therefore, the obtained results reinforce the need for abolition of this practice in all countries, as well as the need for finding safe and effective alternatives to protect public and animal health. Indeed, some alternatives have been developed, such as probiotics, prebiotics, organic acids, enzymes, and modifiers of microbial activity (Santana et al., 2015).

\section{Conclusions}

Overall, the results of the present study showed a great level of resistance to lincomycin, erythromycin, sulfadiazine/trimethoprim, and tetracycline among bacterial respiratory pathogens isolated from pigs in Brazil. Moreover, MDR was also observed in an extensive amount of the isolates, with particularly high percentages among B. bronchiseptica and S. suis strains.

\section{Conflict of interest}

The authors declare that they have no conflict of interest.

\section{Ethics Statement}

Nothing to declare.

\section{Acknowledgements}

This study was supported by Coordenação de Aperfeiçoamento de Pessoal de Nível Superior -Brasil (Capes) (Finace Code 001), Fundação de Amparo à Pesquisa de Minas Gerais (Fapemig) and Conselho Nacional de Desenvolvimento Científico e Tecnológico (CNPq). MS thanks Capes for her fellowship and $\mathrm{MBH}, \mathrm{APL}$ and ZIPL are indebted to CNPq.

Clinical Laboratory Standards Institute. Performance standards for antimicrobial susceptibility testing, M100 [ebook]. 28th ed. Wayne, PA: CLSI; 2018b [cited 2019 Aug 28]. 258 p. ISBN: 1-56238-839-8.

Dayao D, Gibson JS, Blackall PJ, Turni C. Antimicrobial resistance genes in Actinobacillus pleuropneumoniae, Haemophilus parasuis and Pasteurella multocida isolated from Australian pigs. Aust Vet J. 2016;94(7):227-31. http:// dx.doi.org/10.1111/avj.12458. PMid:27349882.

Dayao DAE, Gibson JS, Blackall PJ, Turni C. Antimicrobial resistance in bacteria associated with porcine respiratory disease in Australia. Vet Microbiol. 2014;171(1-2):232-5. http:// dx.doi.org/10.1016/j.vetmic.2014.03.014. PMid:24726505. 
Dutra MC. Uso de antimicrobianos em suinocultura no Brasil: análise crítica e impacto sobre marcadores epidemiológicos de resistência [dissertation]. São Paulo: Universidade Federal de São Paulo, Faculdade de Medicina Veterinária e Zootecnia; 2017.

El Garch F, De Jong A, Simjee S, Moyaert H, Klein U, Ludwig C, Marion H, Haag-Diergarten S, Richard-Mazet A, Thomas V, Siegwart E. Monitoring of antimicrobial susceptibility of respiratory tract pathogens isolated from diseased cattle and pigs across Europe, 2009-2012: VetPath results. Vet Microbiol. 2016;(194):11-22. http://dx.doi.org/10.1016/j. vetmic.2016.04.009. PMid:27102206.

Furian TQ, Borges KA, Laviniki V, Silveira Rocha SL, Almeida CN, Nascimento VP, Salle CTP, Souza Moraes HL. Virulence genes and antimicrobial resistance of Pasteurella multocida isolated from poultry and swine. Braz J Microbiol. 2016;47(1):210-6. http://dx.doi.org/10.1016/j. bjm.2015.11.014. PMid:26887247.

Heres L, Oorburg D, Urlings H. Approaches to reduce antibiotic resistance in the pork supply chain [Internet]. Wageningen: Wageningen Academic Publisher; 2013 [cited 2019 Aug 28]. Available from: http://library.wur.nl/ WebQuery/wurpubs/fulltext/278567

Jong A, Thomas V, Simjee S, Moyaert H, El Garch F, Maher K, Morrissey I, Butty P, Klein U, Marion H, Rigaut D, Vallé $M$. Antimicrobial susceptibility monitoring of respiratory tract pathogens isolated from diseased cattle and pigs across Europe: The VetPath study. Vet Microbiol. 2014;172(12):202-15. http://dx.doi.org/10.1016/j.vetmic.2014.04.008. PMid:24837878.

Kadlec K, Schwarz S. Antimicrobial resistance in Bordetella bronchiseptica. Microbiol Spectr. 2018;6(4). http://dx.doi. org/10.1128/microbiolspec.ARBA-0024-2017.

Kim B, Hur J, Lee JY, Choi Y, Lee JH. Molecular serotyping and antimicrobial resistance profiles of Actinobacillus pleuropneumoniae isolated from pigs in South Korea. Vet Q. 2016;36(3):137-44. http://dx.doi.org/10.1080/0165217 6.2016.1155241. PMid:26879953.

Landers TF, Cohen B, Wittum TE, Larson EL. A review of antibiotic use in food animals: perpective, policy, and potential. Public Health Rep. 2012;127(1):4-22. http:// dx.doi.org/10.1177/003335491212700103. PMid:22298919.

Lönnqvist E, Barkoff AM, Mertsola J, He Q. Antimicrobial susceptibility testing of Finnish Bordetella pertussis isolates collected during 2006-2017. J Glob Antimicrob Resist.
2018;14:12-6. http://dx.doi.org/10.1016/j.jgar.2018.02.012. PMid:29486357.

Magiorakos AP, Srinivasan A, Carey RB, Carmeli Y, Falagas ME, Giske CG, Harbarth S, Hindler JF, Kahlmeter G, OlssonLiljequist B, Paterson DL, Rice LB, Stelling J, Struelens MJ, Vatopoulos A, Weber JT, Monnet DL. Multidrug-resistant, extensively drug-resistant and pandrug resistant bacteria: an international expert proposal for interim standard definitions for acquired resistance. Clin Microbiol Infect. 2011;18(3):268-81. http://dx.doi.org/10.1111/j.14690691.2011.03570.x. PMid:21793988.

Ministério da Agricultura, Agropecuária e Abastecimento (Brasil). Portaria $\mathrm{n}^{\circ}$ 171, de 13 de dezembro de 2018. Informa sobre a intensão de proibição de uso de antimicrobianos com a finalidade de aditivos melhoradores de desempenho de alimentos e abre prazo manifestação. Diário Oficial da União: seção 1. 2018 dez 19 [cited 2019 Aug 28]; (241):23. Available from: http://www.in.gov.br/materia/-/asset_publisher/ Kujrw0TZC2Mb/content/id/55878469

National Committee for Clinical Laboratory Standards. Performance standards for antimicrobial disk and dilution susceptibility tests for bacteria isolated from animals. Approved standard. 2nd ed. Wayne: NCCLS; 2002.

Niemann L, Müller P, Brauns J, Nathaus R, Schäkel F, Kipschull K, Höltig D, Wendt M, Schwarz S, Kadlec K. Antimicrobial susceptibility and genetic relatedness of respiratory tract pathogens in weaner pigs over a 12 -month period. Vet Microbiol. 2018;219:165-70. http://dx.doi.org/10.1016/j. vetmic.2018.03.030. PMid:29778191.

Opriessnig T, Giménez-Lirola LG, Halbur PG. Polymicrobial respiratory disease in pigs. Anim Heal Res Rev. 2011;12(02):13348. http://dx.doi.org/10.1017/s1466252311000120

Palmieri C, Varaldo PE, Facinelli B. Streptococcus suis, an emerging drug-resistant animal and human pathogen. Front Microbiol. 2011;2:1-6. http://dx.doi.org/10.3389/ fmicb.2011.00235. PMid:22275909.

Portis E, Lindeman C. Antimicrobial susceptibility of porcine Pasteurella multocida, Streptococcus suis, and Actinobacillus pleuropneumniae from the United States and Canada, 2001 to 2010. J Swine Health Prod. 2013;21(1):30-41.

Rosco Diagnostica. EUCAST and CLSI-potency NeoSensitabs ${ }^{\text {TM }}$ User's Guide. Taastrup, Denmark; 2013 [cited 2019 Aug 28]. Available from: http://pishrotashkhis.com/ wp-content/uploads/2017/07/Neo-SENSITAB-CLSIEUCAST-Potency.pdf 
Santana MB, Melo ADB, Cruz DR, Garbossa CAP, Andrade C, Cantarelli VS, Costa LB. Alternatives to antibiotic growth promoters for weanling pigs. Cienc Rural. 2015;45(6):10938. http://dx.doi.org/10.1590/0103-8478cr20140407.

Tang X, Zhao Z, Hu J, Wu B, Cai X, He Q, Chen H. Isolation, antimicrobial resistance, and virulence genes of Pasteurella multocida strains from swine in China. J Clin Microbiol. 2009;47(4):951-8. http://dx.doi.org/10.1128/JCM.0202908. PMid:19158260.

World Organisation for Animal Health. OIE Annual report on the use of antimicrobial agents in animals. Paris, France: OIE; 2016 [cited 2019 Aug 28]. Available from: http://www. oie.int/fileadmin/Home/fr/Our_scientific_expertise/docs/ pdf/AMR/Survey_on_monitoring_antimicrobial_agents_ Dec2016.pdf
Zhao Y, Guo L, Li J, Huang X, Fang B. Characterization of antimicrobial resistance genes in Haemophilus parasuis isolated from pigs in China. PeerJ. 2018;6(e4613):1-17. http://dx.doi.org/10.7717/peerj.4613. PMid:29666765.

Zhou X, Xu X, Zhao Y, Chen P, Zhang X, Chen H, Cai X. Distribution of antimicrobial resistance among different serovars of Haemophilus parasuis isolates. Vet Microbiol. 2010;141(1-2):168-73. http://dx.doi.org/10.1016/j. vetmic.2009.05.012. PMid:19564084.

Financial Support: This study was supported by the Coordination for the Improvement of Higher Education Personnel (CAPES) (Finance Code 001), Research Support Foundation of Minas Gerais (FAPEMIG) and the National Council for Scientific and Technological Development (CNPq). MSG thanks CAPES for her fellowship, and $\mathrm{MBH}, \mathrm{APL}$ and ZIPL are indebted to CNPq. 


\section{Supplementary Material}

Supplementary material accompanies this paper.

Supplementary mat. 160956-referencial bibliography of breakpoints

This material is available as part of the online article from http://www.revistas.usp.br/wp/wp-content/uploads/ Suplement_BJVRAS_160956.pdf 